\title{
Synthesizing Grammar and Structure Problems Faced by Indonesian TOEFL Participants
}

\section{Paula L. Hampp ${ }^{1 *}$, Fergina Lengkoan ${ }^{2}$, Tirza A. Kumayas ${ }^{3}$ (D) 2,3 Manado University, Manado, Indonesia}

\section{A R T I C L E I N F O}

Article history:

Received April 16, 2021

Revised April 18, 2021

Accepted May 03, 2021

Available online May 25, 2021

Kata Kunci:

Struktur, Tata Bahasa, TOEFL

Keywords:

Grammar, Structure, TOEFL

DOI:

http://dx.doi.org/10.23887/jpbi.v9 i1.33811

\section{A B S T R A C T}

The TOEFL test is one of the requirements to pass the Thesis exam at several universities in Indonesia. Grammar and Structure Score is the lowest score, and it becomes a problem for the test takers. This study aimed to analyze the factors of Grammar Structure difficulties experienced by students in solving TOEFL questions. This research approach is descriptive qualitative with a sample of 20 students and taken by purposive sampling of 70 students. Interviews and questionnaires were conducted as a data collection tool. The results showed that there were several problems which were factors that influenced the TOEFL participants' written structure and expression lower than listening and reading scores. They cannot analyze the wrong words in part B. A lack of practice on grammar causes problems, and students study independently without guidance and instruction from lecturers or experts. That four main factors cause students to have difficulty solving TOEFL questions: not preparing for the exam, lack of grammar practice, lack of vocabulary mastery, and learning independence. In this case, students and teachers have responsibility for learning achievement, even if these factors come from the TOEFL takers themselves. This is an open-access article under the CC BY-SA license.
Copyright (C) 2021 by Author. Published by Universitas Pendidikan Ganesha. This is an open-access article under the CC BY-SA license.
Copyright (C) 2021 by Author. Published by Universitas Pendidikan Ganesha.

\begin{abstract}
A B S T RA K
Tingoi di Indonesiakan Syarat untuk htuusture Score adalah skor terendah dan itu menjadi masalah bagi para peserta tes. Tujuan dari penelitian ini adalah untuk menganalisis faktor-faktor kesulitan Grammar Structure yang dialami oleh (n) deskriptif kualitatif dengan sampel 20 siswa dan diambil secara purposive sampling
dari 70 siswa. Wawancara dan kuesioner dilakukan sebagai alat pengumpulan data. Hasil penelitian menunjukkan terdapat beberapa masalah merupakan faktor yang mempengaruhi struktur dan ekspresi tertulis peserta TOEFL lebih rendah daripada listening dan reading. Mereka tidak dapat menganalisis kata-kata yang salah di bagian B. Masalah yang disebabkan oleh kurangnya latihan tentang tata bahasa dan asiswa hanya belajar sendiri tanpa bimbingan dan instruksi dari dosen atau ahli. menyelesaikan soal TOEFL, yaitu tidak mempersiapkan diri menghadapi ujian, kurang berlatih grammar, kurang penguasaan kosakata, dan kemandirian belajar. Dalam hal ini siswa dan guru memiliki tanggung jawab terhadap prestasi belajar, bahkan dalam temuan faktor tersebut berasal dari pengambil TOEFL itu sendiri.
\end{abstract}

\section{INTRODUCTION}

The Test of English as a Foreign Language (TOEFL) is an exam that determines whether a student whose native language is not English has strong enough English skills to succeed in courses at a college or university in the United States or Canada (S. Kim, 2021; Smart, 2019). English is the first foreign language in Indonesia and is suitable for test TOEFL as a foreign language (Prastikawati et al., 2021; Simbolon, 2014). The test, which is administered by an agency called the Educational Testing Service, contains four parts: Listening, Structure (which tests knowledge of grammar and mechanics), Reading, and Writing. The Test of English as a Foreign Language (TOEFL) is the standard in the college admissions process, leading to the inclusion of preparation classes in the Intensive English Program (IEP) curricula (E.-Y. J. Kim, 2017; Smart, 2019). The TOEFL is the most widely used assessment of English proficiency by universities. Of 138 institutions surveyed, 100\% used TOEFL as an admission gatekeeper and $86 \%$ of IEP students participate in test-preparation courses either as part of their institution or as a supplemental course (Andrade et al., 2014; G. Ling et al., 2014).

Nowadays TOEFL test is one of the requirements to pass the Skripsi examination of English Education Departments at some Universities in Indonesia, it is also in Manado State University particularly in English Education Department. When the requirement of TOEFL was applied in EED, Grammar and Structure Score was the lowest score and it was a problem for the test takers (Fleckenstein et al., 2020; Hidri \& Roud, 2020). Based on the results of the TOEFL from July 2017 to May 2019 in Language Proficiency Center showed that Grammar and Structure Scores were less than Listening and Reading Scores. In English grammar, sentence structure is the 
arrangement of words, phrases, and clauses in a sentence (E.-Y. J. Kim, 2017; Llosa \& Malone, 2017). Sentence structure may ultimately be composed of many parts, but remember that the foundation of each sentence is the subject and the predicate. The subject is a word or a group of words that functions as a noun; the predicate is at least a verb and possibly includes objects and modifiers of the verb (DeLuca et al., 2013; Guangming Ling, 2017).

The test, which is administered by an agency called the Educational Testing Service, contains four parts: Listening, Structure (which tests knowledge of grammar and mechanics), Reading, and Writing. In TOEFL there are three Sections, Listening, Structure and Written Expression, and the Last Reading (Riazi, 2016; Staples et al., 2013). In Listening there are 50 numbers, Structure and Written Expression there are 40 numbers, and Reading there are 50 numbers. In Structure and written expressions, structure start from number 1 till number 15, and written expressions start from number 16 till number 40 (Alavi \& Akbarian, 2020; Masfufah, 2018). Even though Structure and written expressions only 40 numbers but it should be done in 25 minutes. The Structure section tests your understanding and usage of standard written English. You will answer two types of questions in the Structure section of the TOEFL test. The first type of question is an incomplete sentence with four choices of words or phrases to complete the sentence. The second type of question requires you to identify a word or phrase in an incorrect sentence. On the computer-based version of the TOEFL test, the two types of questions are interspersed throughout the Structure section (Destiyanti et al., 2021; Zarei \& Afshar, 2014).

Previous research findings indicate that most students do not have good preparation in exams, and teaching centers are not produced in the form of essays but only structures (Putra et al., 2020; Tanihardjo, 2016). Other studies also state that students' mistakes are ignorance, carelessness, hesitation, unconsciousness, and wrong choice when doing tests (Hajri et al., 2018; E.-Y. J. Kim, 2017). This research is considered significant because it focuses on students' problems in facing the TOEFL test, namely to find out the factors of the TOEFL taker and the grammar section. There is no in-depth study of grammar and structure problems faced by TOFEL Indonesia participants. The purpose of this study is to analyze the grammatical and structural problems faced by Indonesian TOFEL participants. It is hoped that this research can solve problems regarding difficulties in grammar and structure faced by Indonesian TOFEL participants.

\section{METHOD}

In this study the researcher used Qualitative Research, synthesizing qualitative research. In qualitative research, collecting the data was done in participant observation, depth interviews, and documentation. In this research, the writer used interviews supported by questionnaires and documentation. The interview is an activity that involves the interviewer and interviewee where the interviewer will give some questions to be answered by the interviewee. Based on the types of the interview above, the writer used one-on-one interview. According to him, a one-on-one interview was data collection processing in which the writer asked the questions and recorded answers from only one participant in the study at a time (Suharsaputra, 2012). The writer prepares eight questions to relate to Grammar Structure, TOEFL test, TOEFL scores, and the difficulties in the TOEFL test. To collect data from the interview, the writer made some procedures. Those were (1) preparing the concept of questions that want to be asked to subject and (2) the writer transcripts the result of the interview. In this research, the writer made fifteen items statements relate to beliefs in Grammar Structure, TOEFL test, TOEFL scores, and the difficulties in the TOEFL test. This questionnaire was used to support and get the validity of interviews to relate to Grammar Structure, TOEFL test, TOEFL scores, and the difficulties in the TOEFL test. The questionnaire was distributed before the writer interviewed the subject. After collecting the data, the writer analyzed the data.

\section{RESULT AND DISCUSSION}

\section{Result}

In this section, the researcher discussing the results of the interview which involved 20 students as the samples. The 20 students were chosen based on the data that students have taken TOEFL Test. The section concern the structure and written expression questions which most students had finished and failed. In addition, the focus of the interview was significantly to find out the TOEFL takers' problems in responding to the structure and written expression section. There were five questions which are asked by the researcher in the interview: 1) What is your last TOEFL score ?, 2) How many times do you take TOEFL test?, 3) How many hours do you spend studying every day/week to prepare your test?, 4) What are your problems or difficulties in structure and written expression section in the TOEFL?, 5) What is your strategy to answer Structure and Written expression?.

Based on the result data of interview above in question number 3 about TOEFL takers' readiness to follow the TOEFL test from 20 interviewees, 2 students prepare themselves every day, 7 students prepare themselves each week, 9 students prepare themselves a day before the test, and 2 students do not prepare themselves for the test. No practice and less practice were the factors of TOEFL takers' problems in TOEFL test, we know that in TOEFL test there were three sections, the Listening Section was approximately 30 minutes, Structure and Written 
Expression was 25 minutes, and Reading Section was 55 minutes. Munadia (2016) stated that “By practicing, the students might be familiar with the test. In this case, grammar 5252 practice is the crucial one" TOEFL test took about 2 hours, therefore, how can They get a good score of structure if they no prepare, less practice, and just spent 30 minutes or an hour each week for TOEFL test.

Based on the result data of interview above in question number 4 about TOEFL takers' problems in grammar and structure section from 20 interviewees, 1 student have no problem, 4 students have problems in part A incomplete sentence, and 15 students have problems in part B identify the one underlined word or phrase that must be changed for the sentence to be correct. The result of the interview showed that $75 \%$ of problems in part B where the students have to find out which one word or phrase is incorrect. They could not analyze the incorrect word or phrase and it was a factor influencing their score of structure and written expression was lower than listening and reading score. Munadia's (2016) research showed that "The first important factor was due to the lack of grammar mastery among the students" it also happens this research. Lack of comprehension in grammar structure was a problem in the TOEFL test, the students have to understand the model of questions, the basics of TOEFL grammar, and mastering of Vocabulary.

Based on the result data of interview above in question number 5 about TOEFL takers' strategy to answer grammar and structure from 20 interviewees, 1 student answer no idea for the strategy, 1 student answer just feeling, 2 students answer by watching youtube about grammar structure, 2 students answer buying grammar and TOEFL book, and 14 students answer more practice and learn about grammar structure. They just practice by themselves without tutorials from lecturers or experts, even though learning autonomy is effective for students to improve their skills but it will be better if they can get tutorials and instructions from lecturers or experts they have learned grammar structure from the first semester until the fourth semester in four subjects, there were basic English grammar, pre-intermediate English grammar, intermediate English grammar, and advanced English grammar. Even though it was enough for them to understand grammar structure.

Based on the analysis of student responses regarding "I have fulfilled the minimum score of 475 " it showed that 6 responses choose "No" 30\% and 14 responses choose "Yes" $70 \%$ from 20 responses. Based on the analysis of student responses regarding" showed that 10 responses choose "No" $50 \%$ and 10 responses choose "Yes" 50\% from 20 responses. Based on the analysis of student responses regarding "The time for structure and written expression is not enough for me "that 4 responses choose "No" $20 \%$ and 16 responses choose "Yes" $80 \%$ from 20 responses. Based on the analysis of student responses regarding "The questions in structure and written expression sections I did not learn before" it showed that 19 responses choose "No" 95\% and 1 reason choose "Yes" 5\%Belum 20 responses. The statement "Soal-soal Structure and Written Expression belum pernah saya pelajari selama perkuliahan" means that the material that used in the TOEFL test about the structure and written expression already TOEFL takers learned and they have to more practice and reopen their knowledge about grammar structure. Based on the analysis of student respond written expression need more practice and learning related to the structure and writtenexpression in the TOEFL test" that 1 reason choose "No" $1 \%$ and 19 reasons choose "Yes" 95\% from 20 responses. The statement "Saya ingin mendapatkan pelatihan atau pembelajaran tambahan tentang Structure and Written Expression" get 95\% to choose "Yes" it means that TOEFL takers need more practice related to Structure and Written Expression in TOEFL, even though the materials about grammar and written expression they already learned from the first semester until the fourth semester.

\section{Discussion}

Based on the findings above it showed that the TOEFL takers' problems in structure and written expression section influenced by some factors. So many EFL students find learning English to be a complex subject for many reasons (Muhammed, 2014; Zhang, 2021). In this research, they have some reasons. First, they did not prepare for the test. The second factor was less practice of grammar. Most of them did not have well prepared for the test (Alavi \& Akbarian, 2020; Riazi, 2016). However, when we prepare, such as practice TOEFL test, we understand to manage the time, the strategy and know the clue of questions related to the structure and written expressions (E.-Y. J. Kim, 2017; Smart, 2019). It also can be seen in finding table 3 where the statement "I need more time in finishing structure and written expressions section" the data showed $80 \%$ answered yes and $20 \%$ answered no.

Use time as effectively as possible, because strategy is the important thing you just need to focus on part A complete sentence correctly and part B find out the word or phrase that is incorrect (S. Kim, 2021; Llosa \& Malone, 2017). The third factor was lack of vocabulary mastery, we know that three components in English are vocabulary, grammar structure, and pronunciation. Skill and component have integrated each other, where how can they understand in reading and listening if they did not enough vocabulary also in structure and written expression they could not answer correctly if they did not have stock of vocabulary (Destiyanti et al., 2021; Staples et al., 2013). In addition, the TOEFL takers are students of the English Education Department where they focus on learned English for more than three years and lack of vocabulary is not the big factor when they learned English for more than three years this can help them familiar with English vocabulary. It is supported with data in table 4 
where the statement "The questions of structure and written expression I did not learn before in the learning process" 5\% answered yes and 95\% answered no.

The last factor is learning autonomy, the statement "I need training from lecturer or expert to train-related to the structure and written expression" and 95\% answered yes and 5\% answered no. They need structure training and written expression, thought of lecturer and researcher have a different side where are from differences could be findings to solve and synthesizing the difficulties that come from cause and effect (Amiryousefi \& Tavakoli, 2011; Hidri \& Roud, 2020). While for structure and written expression collected the grammar structure understanding, read the instruction each part also could help them to understand what they have to do in that section (Fleckenstein et al., 2020; Masfufah, 2018). Overall based on findings in interview question number 4 "What are your problems or difficulties in structure and written expression section in the TOEFL?" found that 75\% of problems in part B, this part are different because TOEFL takers should find out the phrase or word that is incorrect. The role when they learned English particularly grammar before they just tried and practice for correct grammar, accordingly they need to high criticism in English Grammar when they should know what is incorrect and what is correct (Alavi \& Akbarian, 2020; Riazi, 2016).

\section{CONCLUSION}

The problems were the factors that influenced TOEFL takers' structure and written expression was lower than listening and reading's score. They could not analyze the incorrect words in part B. the problems were caused by less practice about grammar and they just learn by themselves without tutoring and instructions from the lecturer or expert. It can be concluded that some factors were Not prepared for a test, less practice of grammar, lack of vocabulary mastery, and learning autonomy. In this case, students and teachers have responsibility for learning achievement, even in the findings, the factors come from the TOEFL taker itself.

\section{REFERENCES}

Alavi, S. M., \& Akbarian, I. (2020). The role of vocabulary size in predicting performance on TOEFL reading item types. System, 40(3). https://doi.org/10.1016/j.system.2012.07.002

Amiryousefi, M., \& Tavakoli, M. (2011). The Relationship between Test Anxiety, Motivation and MI and the TOEFL iBT Reading, Listening and Writing Scores. Procedia - Social and Behavioral Sciences, 15. https://doi.org/10.1016/j.sbspro.2011.03.075

Andrade, M. S., Evans, N. W., \& Hartshorn, K. J. (2014). Linguistic support for non-native English speakers: Higher education practices in the United States. Journal of Student Affairs Research and Practice, 51(2). https://doi.org/10.1515/jsarp-2014-0020.

DeLuca, C., Cheng, L., Fox, J., Doe, C., \& Li, M. (2013). Putting testing researchers to the test: An exploratory study on the TOEFL iBT. System, 41(3). https://doi.org/10.1016/j.system.2013.07.010

Destiyanti, C., Amin, M., \& Putera, L. J. (2021). Gender-Based Analysis of Students' Ability in Answering Factual and Vocabulary-in-Context Questions of the TOEFL-Like Reading Comprehension Test. Palapa: Jurnal Studi Keislaman Dan Ilmu Pendidikan, 9(1). https://doi.org/10.36088/palapa.v9i1.926

Fleckenstein, J., Keller, S., Krüger, M., Tannenbaum, R. J., \& Köller, O. (2020). Linking TOEFL iBT® writing rubrics to CEFR levels: Cut scores and validity evidence from a standard setting study. Assessing Writing, 43. https://doi.org/10.1016/j.asw.2019.100420

Hajri, T., Jufrizal, J., \& Wahyuni, D. (2018). An Analysis of Difficulties In Answering Structure and Written Expression of TOEFL Made by English Students of Universitas Negeri Padang. English Language Teaching, 7(1). https://doi.org/10.24036/jelt.v7i1.8957

Hidri, S., \& Roud, L. F. P. (2020). Developing and using hints in computerized dynamic assessment of a TOEFL iBT reading exam. Heliyon, 6(9). https://doi.org/10.1016/j.heliyon.2020.e04985

Kim, E.-Y. J. (2017). The TOEFL iBT writing: Korean students' perceptions of the TOEFL iBT writing test. Assessing Writing, 33. https://doi.org/10.1016/j.asw.2017.02.001

Kim, S. (2021). Prepping for the TOEFL iBT Writing test, Gangnam style. Assessing Writing, 49. https://doi.org/10.1016/j.asw.2021.100544

Ling, G., Powers, D. E., \& Adler, R. M. (2014). Do TOEFL iBT® scores reflect improvement in English-language proficiency? Extending the TOEFL iBT validity argument. ETS Research Report Series, 1. https://doi.org/doi:10.1002/ets2.12007.

Ling, Guangming. (2017). Are TOEFL iBT® writing test scores related to keyboard type? A survey of keyboardrelated practices at testing centers. Assessing Writing, 31. https://doi.org/10.1016/j.asw.2016.04.001

Llosa, L., \& Malone, M. E. (2017). Student and instructor perceptions of writing tasks and performance on TOEFL iBT versus university writing courses. Assessing Writing, 34. https://doi.org/10.1016/j.asw.2017.09.004

Masfufah, S. (2018). Indonesian College Students' Perceptions Of Toefl Preparation Class. Edulite: Journal Of 
English Education, Literature, And Culture, 3(1). https://doi.org/10.30659/e.3.1.66-78

Muhammed, A. A. (2014). The Impact of Mobiles on Language Learning on the Part of English Foreign Language (EFL) University Students. Procedia - Social and Behavioral Sciences, 136. https://doi.org/10.1016/j.sbspro.2014.05.297

Prastikawati, E. F., Wiyaka, W., \& Budiman, T. C. S. (2021). Pelatihan Penyusunan Soal Bahasa Inggris Berbasis HOTS bagi Guru Bahasa Inggris SMP. Jurnal Pengabdian Masyarakat, 6(1). https://doi.org/10.30653/002.202161.761

Putra, A., Lubis, R. F., \& Siregar, S. R. (2020). An Analysis on English Students' Difficulties in TOEFL test of Structure and Written Expression Section at IAIN Padangsidimpuan Rahmadhani Siregar. International Online Conference on English and Education, 1(1). http://jurnal.iainpadangsidimpuan.ac.id/index.php/ioctbi/article/view/4129

Riazi, A. M. (2016). Comparing writing performance in TOEFL-iBT and academic assignments: An exploration of textual features. Assessing Writing, 28. https://doi.org/10.1016/j.asw.2016.02.001

Simbolon, N. (2014). Pengaruh Pendekatan Pembelajaran Dan Kemampuan Verbal Terhadap Kemampuan Berbicara Bahasa Inggris Siswasma Negeri 14 dan 21 Medan. Cakrawala Pendidikan, 33(2). https://journal.uny.ac.id/index.php/cp/article/view/2149/pdf

Smart, J. (2019). Affordances of TOEFL writing tasks beyond university admissions. Assessing Writing, 41. https://doi.org/10.1016/j.asw.2019.06.006

Staples, S., Egbert, J., Biber, D., \& McClair, A. (2013). Formulaic sequences and EAP writing development: Lexical bundles in the TOEFL iBT writing section. Journal of English for Academic Purposes, 12(3). https://doi.org/10.1016/j.jeap.2013.05.002

Suharsaputra, U. (2012). Metode Penelitian Kuantitatif, Kualitatif, dan Tindakan. PT Refika Aditama.

Tanihardjo, J. (2016). The Analysis of Students' English Competence in the Grammar Section in the Paper-Based TOEFL: A Case Study at English Department in Bunda Mulia University. Journal of English Language \& Culture, 6(1). https://doi.org/10.30813/jelc.v6i1.270

Zarei, A. A., \& Afshar, N. S. (2014). Multiple Intelligences As Predictors Of Reading Comprehension And Vocabulary Knowledge. Indonesian Journal Of Applied Linguistics, 4(1). https://doi.org/10.17509/ijal.v4i1.598

Zhang, Y. (2021). Combining computer-mediated communication with data-driven instruction: EFL learners' pragmatic development of compliment responses. 103. https://doi.org/10.1016/j.system.2021.102624 